\title{
Survey of thrips in Sri Lanka: A checklist of thrips species, their distribution and host plants
}

\author{
Kalpana Tillekaratne $^{1,2}$, J.P. Edirisinghe ${ }^{1 *}$, C.V.S. Gunatilleke ${ }^{3}$ and W. A. I. P. Karunaratne ${ }^{1}$ \\ ${ }^{1}$ Department of Zoology, Faculty of Science, University of Peradeniya, Sri Lanka \\ ${ }^{2}$ Postgraduate Institute of Science, University of Peradeniya, Sri Lanka \\ ${ }^{3}$ Department of Botany, Faculty of Science, University of Peradeniya, Sri Lanka \\ Accepted 08 November 2011
}

\begin{abstract}
Thrips of Sri Lanka have been poorly studied despite their significance to agriculture and horticulture of the country. A survey of thrips and their host plants was conducted in several parts of Sri Lanka during 2005-2008, with a view to record the species present, their distribution, host plant relationships and damage caused. Over 1,000 plant species comprising crops, ornamental plants, weeds, shrubs, and trees were examined for thrips in 22 study sites, representing a range of habitats in nine districts covering 12 agrochemical regions of the country. Damage in plants due to thrips infestations was documented. This paper presents a list of 72 thrips species in 45 genera recorded during the survey from 324 host plant species in 83 plant families. Megalurothrips usitatus, Thrips palmi, and Haplothrips gowdeyi were the most widely distributed species. The grass infesting Haplothrips spp., several species of Thrips, Microcephalothrips abdominalis, M. usitatus and Scirtothrips dorsalis are some of the species with a large number of host records. Thrips simplex in particular was confined to the Upcountry Wet zone, while Thrips flavus was most widespread in this region and was present on almost all the vegetation. The survey identified 24 species of thrips represented in 20 genera that were not recorded previously from Sri Lanka. Majority of the thrips recorded are pest species, cosmopolitan in distribution. The most common damage due to thrips infestations was discolouration, scarring and browning of leaves and flowers, most pronounced in cut flowers. The survey updates the information on the Thysanoptera of Sri Lanka and highlights their importance in agriculture and floriculture.
\end{abstract}

Key words: agriculture, floriculture, damage, pest species, new records

\section{INTRODUCTION}

Thrips (Order Thysanoptera) of the world comprise 5500 species in 750 genera (Moritz et al., 2004). They are more common in warmer tropical parts of the world than in the temperate regions. About $50 \%$ of them are fungal feeders, while $40 \%$ feed on living tissues of dicotyledonous plants and grasses and the balance exploit primitive plants or are predatory (Morse and Hoddle, 2006). Species infesting higher plants are found on leaves, shoots, flowers, flower buds, axillary buds, young fruits and cones of Conifers (Lewis, 1973). Others inhabit lichens, mosses, ferns, dead tree trunks and leaf litter (Mound, 2004). Those infesting living tissues of plants are sap feeders while flower dwelling species feed on pollen. A few predate on mites, scale insects and other thrips (Mound, 2004).

Thrips play destructive as well as beneficial roles in agriculture. They are plant pests (Lewis, 1973; Morse and Hoddle, 2006) causing scarring and silvering of leaves, petals and fruits, premature flower fall, pollen depletion, leaf shedding and also leaf deformity. They also form leaf galls (Lewis, 1973; Raman \& Ananthakrishnan, 1984). Furthermore, thrips are important vectors of tospoviruses that cause serious crop losses around the world (Mound, 1996; Lewis, 1973). Predatory, species such as Franklinothrips orizabensis have been used in the biological control of Scirtothrips persea (Hoddle et. al., 2004). Thrips are increasingly being recognized as plant pollinators (Mound, 2004) in plants as diverse as oil palm (Syed, 1979) and rainforest trees (Nyree et al., 2004).

The thrips of the Indian subcontinent have been extensively documented by Ananthakrishnan and Sen (1980) and Bhatti (2004a and b). Ananthakrishnan (1980) gives a key to all recorded Indian species of thrips and their host plants. Thrips of Sri Lanka have been poorly studied despite their significance to agriculture and horticulture of the country. The first extensive account of the Order

*Corresponding author's email: jpediri@pdn.ac.lk 
Thysanoptera in Sri Lanka is by Schmutz (1913) where a total of 43 species are included. Thereafter, three Haplothrips species from Sri Lanka were recorded by Pitkin (1976) with their distribution and host plants. Many years later, some of the fungus feeding thrips of Sri Lanka was discussed in an account of nine genera of thrips from the Oriental region (Mound and Palmer, 1983). More recently, Oda et al. (1997) recorded thrips from ornamental plants in Sri Lanka. Wijerathna (1999) compiled a list of 18 species of thrips from 28 crop species, along with many other pests from a wide variety of crops, largely from unpublished records of the Department of Agriculture. The CABI/International crop protection compendium lists 16 species from Sri Lanka that are common pest thrips. A comprehensive list of Thysanoptera of Sri Lanka comprising 78 species in 46 genera was compiled from published literature and museum records, dating from 1913 up to the present survey by Tillekaratne et al. (2007).

Since the pioneering work of Schmutz in 1913 and later by a few others on selected economic crops, a recent field study has not been conducted on thrips and their host plants in Sri Lanka. As thrips have increasingly become pests of crops, it is important to document the current distribution and host range of thrips as well as the damage they inflict. Also, it is important to know the status of potential pest species since the early records. The present survey thus updates the information on the Thysanoptera of Sri Lanka and highlights their importance in agriculture and floriculture.

\section{MATERIALS AND METHODS}

\section{Collection sites}

Field collection of thrips was carried out in 22 sites located in nine administrative districts covering four climatic zones and 7 agroecological regions of the country. The selected sites are located at different elevations in the Dry, Wet, Intermediate and Montane Zones of the country. Selection of collection sites was based on accessibility, agroecological regions, proximity to Agricultural Research Stations, vegetation type and habitat type. Financial constrains for travel limited the number of visits to distant sites. The Northern and Eastern Provinces of the country were not included in the survey due to the civil unrest that prevailed in these areas during the study period. The locations of the 22 study sites in relation to the agro ecological regions of the country are shown in Fig. 1.

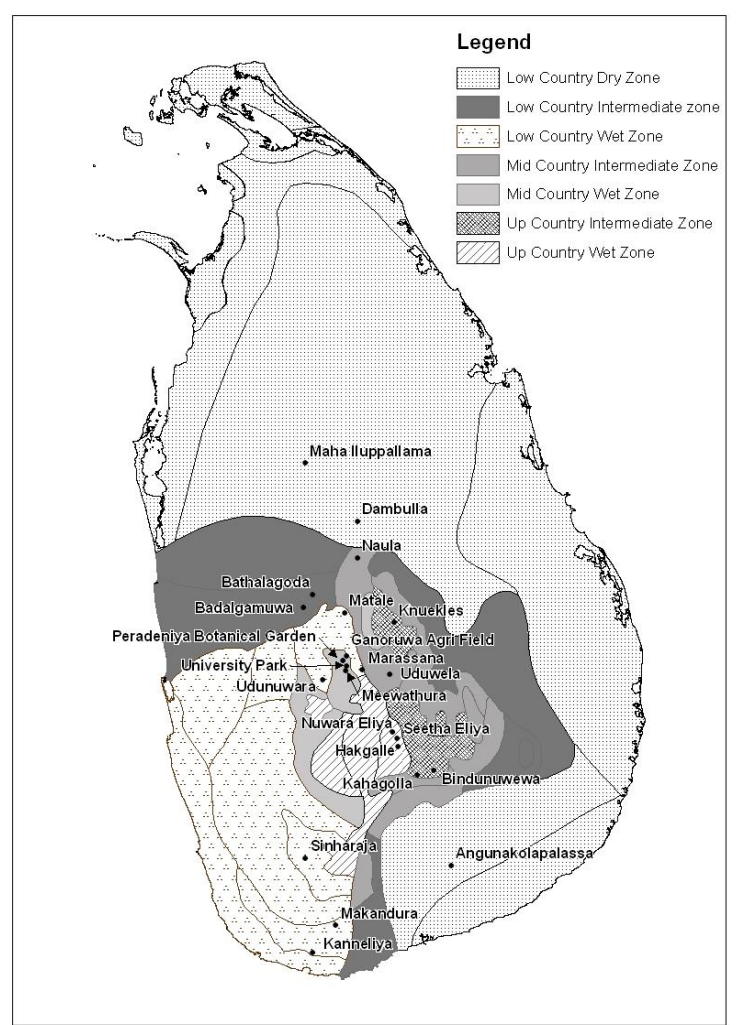

Figure 1. Locations of collection sites in relation to agroecological regions of Sri Lanka. 
The 22 collecting sites represented the following habitat categories:

\section{Agricultural fields (AF)}

Agricultural Research Stations, farmer fields and crop nurseries in Gannoruwa, MahaIlluppallama, Sita Eliya, Bandarawela, Makandura, Angunakolapalassa, Bathalagoda, Dambulla, Marassana and Naula.

\section{Floricultural fields (FF)}

Royal Botanical Gardens at Peradeniya, Hakgala Botanical Gardens, Peradeniya University Park and several cut flower farms in Nuwara Eliya and Bandarawela.

\section{Natural Forests (NF)}

Knuckles forest reserve, Sinharaja rain forest, Badalgamuwa forest reserve, Kanneliya forest reserve.

\section{Disturbed Habitats (DH)}

Road sides, foot paths, home gardens, fallow rice fields, weedy patches and grasslands in different collection sites.

\section{Collection of Thrips}

At each collection site, natural and cultivated vegetation (crops, ornamental plants, shrubs and trees) and weeds were checked for thrips. Different plant parts were closely examined for populations of thrips and individuals hand collected using a fine brush in to the collecting fluid; a mixture of alcohol, glycerol and acetic acid (AGA). Thrips on small branches were collected using a beating tray. At the time of collection, location of thrips on the plant and the type of damage observed due to thrips infestation were recorded. Felled tree trunks, freshly cut timber, logs and leaf litter were examined for fungus feeding thrips. Leaf litter samples collected $\left(50 \mathrm{~m}^{2}\right)$ were extracted in Berlese funnels.

\section{Identification of thrips}

Thrips were identified using taxonomic keys, digital images and descriptions of Mortiz et al. (2001), Moritz et al. (2004), Ananthakrishnan \& Sen (1980), Palmer (1980), Palmer and Mound (1978). In addition, keys of Wilson (1975) and Pitkin (1976) were used for specific subfamilies and genera. The identity of difficult species and those previously not recorded form Sri Lanka were confirmed by Dr. L.A. Mound, Honorary Research Fellow, CSIRO Entomology, Australia, and Prof. J. S. Bhatti, New Delhi, India.

\section{Identification of host plants of thrips}

Plants infested with thrips and habouring a population were considered as host plants. Well known common cultivated plants and weeds were identified in the field itself and others through herbarium specimens identified with help from the Department of Botany, University of Peradeniya and the National Herbarium, Peradeniya.

\section{Identification of thrips damage}

In thrips infested plants, different plant parts such as leaves, flowers, flower buds and fruits were closely examined for thrips damage and checked for probable signs of viral infection such as curling, crumpling and leaf discolouration. Leaves of plants with morphologically distinct galls were collected and examined for thrips.

\section{RESULTS}

Thrips recorded during the survey are given in an annotated, systematic list (Appendix 1) arranged according to the classification of Mound and Kibby (1998). The distribution of each thrips species is stated in relation to the collection site/agroecological region/climatic zone. Host plants of each thrips species is arranged alphabetically according to genera and species (family). The type of damage in host plants due to thrips infestation is stated under each species. Pest thrips species and species previously not recorded from Sri Lanka are also indicated.

\section{Thrips species recorded}

A total of 72 species of thrips in 45 genera, belonging to 5 subfamilies were recorded during the survey. Of them, 57 were identified to species level, 9 to generic level and 6 to subfamily level. Subfamily Thripinae included the most number of species (34) and genera (18). Subfamily Phlaeothripinae was represented by 16 species in 11 genera making it the second largest subfamily of thrips, followed by subfamily Panchaetothripinae that included 12 species in 11 genera. Each of the remaining subfamilies; Dendrothripinae and Idolothripinae included only 2- 4 species. Genus Thrips was the most speciose with 13 species, while each of the remaining genera was represented by 1-3 species only.

Among the thrips collected and identified during the survey are 18 genera and 25 species not previously recorded form Sri Lanka, according to the checklist of Tillekratne et al., 
(2007). The 18 newly recorded genera are Astrothrips, Elixothrips, Oneilliella, Ayyaria, Arorathrips, Ceratothripoides, Craspedothrips, Dendrothripoides, Dichromothrips, Ernothrips Rhamphothrips, Dolichothrips, Gynaikothrips, Karnyothrips, Membrothrips, Praepodothrips and Sphingothrips. The identity of these new genera was confirmed by Prof. J. Bhatti of India and these genera are also known from India. The 25 new species recorded represented a single species each in 18 of the new genera together with Caliothrips luckmanni, 4 species in the genus Thrips and an unidentified species each in the genera Gynaikothrips and Haplothrips. The identity of these newly recorded species too was confirmed by Prof. J. S. Bhatti and they are also known from India. No endemic species of thrips were recorded. Of the recorded genera and species of thrips, 42 are cosmopolitan pest species and 5 are potential viral vector species according to Moritz et al. (2001). The most common thrips species recorded was Haplothrips gowdeyi, found on 44 of the 324 host plant species identified and was present in almost all the collection sites. Thrips palmi was the second most common species and was recorded from 43 plant species.

\section{Distribution of thrips}

The 22 collection sites are distributed in the Dry (03 sites), Wet (11 sites), and Intermediate Zones (08 sites) of the country. Hence, the survey included more Wet zone collection sites that resulted in a higher number of thrips species (234 spp.) and thrips infested plant species (in 68 genera) being recorded from the Wet zone (Fig. 2). Although, there was a marked difference in the number of thrips infested plant species in the 3 climatic zones, the number of thrips species infesting these plants did not show a marked difference, but varied from $33-48$ species in 18-23 genera.

The 22 collection sites came under 7 agroecological regions. Each of these 7 agroecological regions were represented by three or more collection locations except the Low Country Wet Zone (1 location) and Upcountry Intermediate Zone (2 locations). The number of thrips infested plant species and the number of thrips species recorded from each collection site and in each agro ecological region are given in Table 1. The largest number of thrips species (175 spp.) and thrips host species (43 spp.) were recorded from the Mid country Wet zone

In terms of individual collection sites, from Angunakolapellassa, located in the Low Country Dry zone, the largest number of thrips (25 species in 15 genera) and host plants (61 species in 26 families) were recorded. Peradeniya University Park located in the Midcountry Wet zone had the second largest collection of thrips infested plant species and thrips species. Kahagolla in the Upcountry Intermediate zone had the third highest number of thrips infested plants and thrips species.

Thrips flavus in particular was abundant and widely distributed in the Upcountry Wet zone collection sites; Hakgala, Nuwara Eliya and, Sita Eliya (Fig.3). In this agroecological region almost all flowering plants were infested with this species. In collection sites of other agroecological regions this trend was not observed as shown in Fig.3. Furthermore, Thrips simplex in particular was recorded only from the Upcountry Wet zone. In the Dry zone, Retithrips syriacus was very common on mature leaves.

Many of the collection sites were agricultural habitats widely distributed in all the climatic zones, agroecological regions and at several elevations. The crops grown in these different agricultural habitats were largely vegetables, a few fruit crops and rice. These economic plant categories included the highest number of thrips infested plant hosts (156 plant species in 50 plant families). Forty five species of thrips in 28 genera infested the agricultural crop species. A similar number of thrips infested plant species (151 spp.) were recorded from disturbed habitats comprising fallow rice fields, home gardens, weedy patches/scrub and road sides; from where 37 thrips species were recorded. From floricultural sites, 26 thrips species were recorded from 75 species of flowers. The natural forest habitats supported the least number of thrips host plant species (51 spp.) that harboured only 26 thrips species.

\section{Host plant relationships of thrips}

Over 1000 plant species were examined for thrips during the study. Thrips were present on 347 plant species. Of them, established populations of thrips species were present only in 324 plant species in 83 families. The other 23 plant species harboured only a few individuals of one or more thrips species. A total of 69 species of thrips were recorded from 324 plant species in 83 plant families. Of the plant families, Poaceae, Asteraceae, Fabaceae, ranked first, second and third, respectively, harbouring the most number of thrips species and genera. Poaceae with 38 species of grasses and Cyperaceae with 5 species of sedges harboured 6 different thrips species. Asteraceae with 38 host plant species harboured 11 different thrips species and Fabaceae with 36 spp. of host plants recorded 16 species of thrips. 


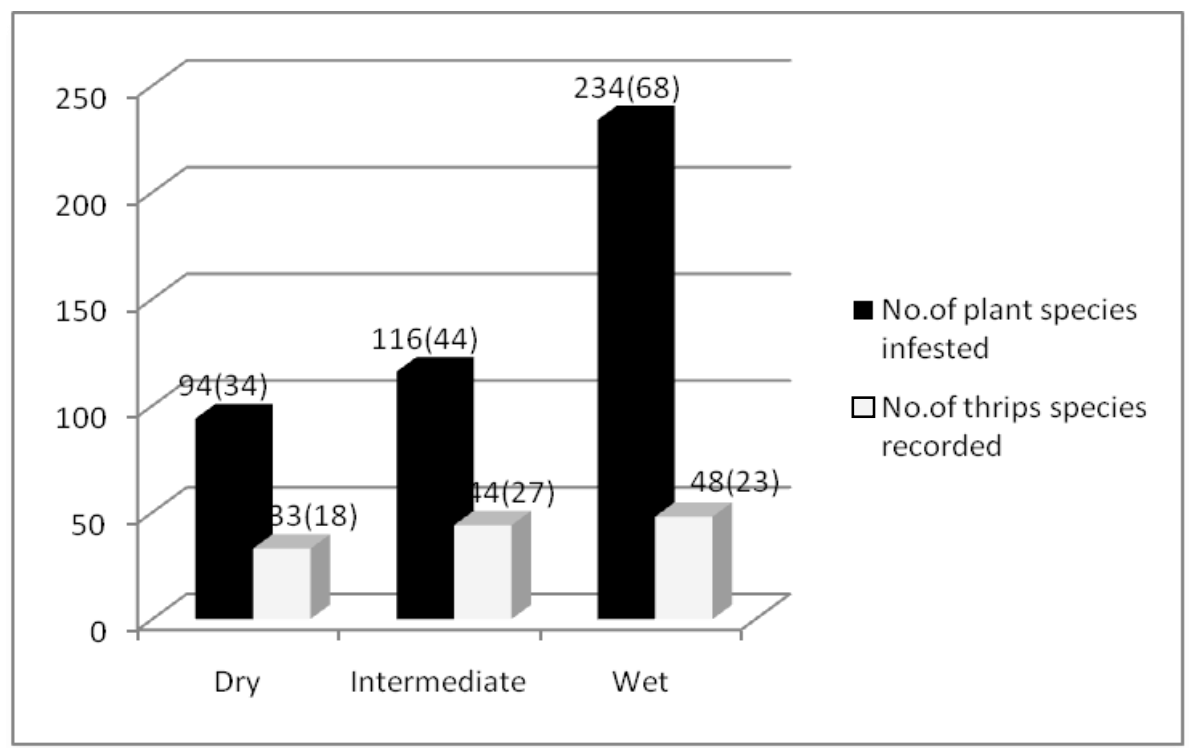

Figure 2. Distribution of thrips species and their host plant species in the major climatic zones of Sri Lanka. ( ) No. of genera recorded

Table1. Number of thrips species and their host plants in different collection sites, agroecological regions and habitats.

\begin{tabular}{|c|c|c|}
\hline Collection site \& Agroecological region (Habitats) & $\begin{array}{l}\text { No. of host species } \\
\text { (Families) }\end{array}$ & $\begin{array}{c}\text { No. of Thrips species } \\
\text { (Genera) }\end{array}$ \\
\hline Low Country Dry Zone & $94(34)$ & $33(19)$ \\
\hline Angunakolapellassa (AF, DH) & $61(26)$ & $26(15)$ \\
\hline Dambulla (AF, DH) & $21(11)$ & $14(10)$ \\
\hline Maha Illuuppallma (AF, DH) & $38(20)$ & $23(16)$ \\
\hline Low Country Intermediate Zone & $26(14)$ & $20(12)$ \\
\hline Badalgamuwa (NF) & $01(01)$ & $01(01)$ \\
\hline Bathalagoda (DH) & $13(05)$ & $10(07)$ \\
\hline Makandura (AF, DH) & $12(08)$ & $11(08)$ \\
\hline Low Country Wet Zone & $04(02)$ & $02(02)$ \\
\hline Kanneliya (NF) & $04(02)$ & $02(02)$ \\
\hline Mid Country Intermediate Zone & $48(21)$ & $22(12)$ \\
\hline Knuckles (NF, AF) & $35(19)$ & $16(09)$ \\
\hline Matale (AF, DH) & $11(08)$ & $12(10)$ \\
\hline Naula (AF, DH) & $07(03)$ & $05(05)$ \\
\hline Mid Country Wet Zone & $175(51)$ & $43(21)$ \\
\hline Gannoruwa (AF) & $21(13)$ & $12(08)$ \\
\hline Marassana $(\mathrm{AF}, \mathrm{DH})$ & $32(13)$ & $11(05)$ \\
\hline Meewathura (AF) & $20(10)$ & $15(07)$ \\
\hline Peradeniya Botanical gardens (FF) & $40(24)$ & $21(13)$ \\
\hline Peradeniya University park (FF, DH) & $59(26)$ & $21(13)$ \\
\hline Sinharaja (NF, AF) & $21(12)$ & $13(09)$ \\
\hline Udunuwera (DH) & $11(05)$ & $05(04)$ \\
\hline Up Country Intermediate Zone & $58(24)$ & $26(17)$ \\
\hline Bidunuweva (AF) & $16(08)$ & $14(10)$ \\
\hline Kahagolla (AF, DH) & $48(23)$ & $21(15)$ \\
\hline Up Country Wet Zone & $69(35)$ & $23(11)$ \\
\hline Hakgalle (FF, DH) & $39(24)$ & $16(08)$ \\
\hline Nuwera Eliya (AF, DH, FF) & $27(15)$ & $08(04)$ \\
\hline Sita Eliya (AF, DH, FF) & $22(16)$ & $15(10)$ \\
\hline
\end{tabular}

AF - Agricultural fields, DH - Disturbed habitats, NF -Natural forests, FF-Floriculture fields 

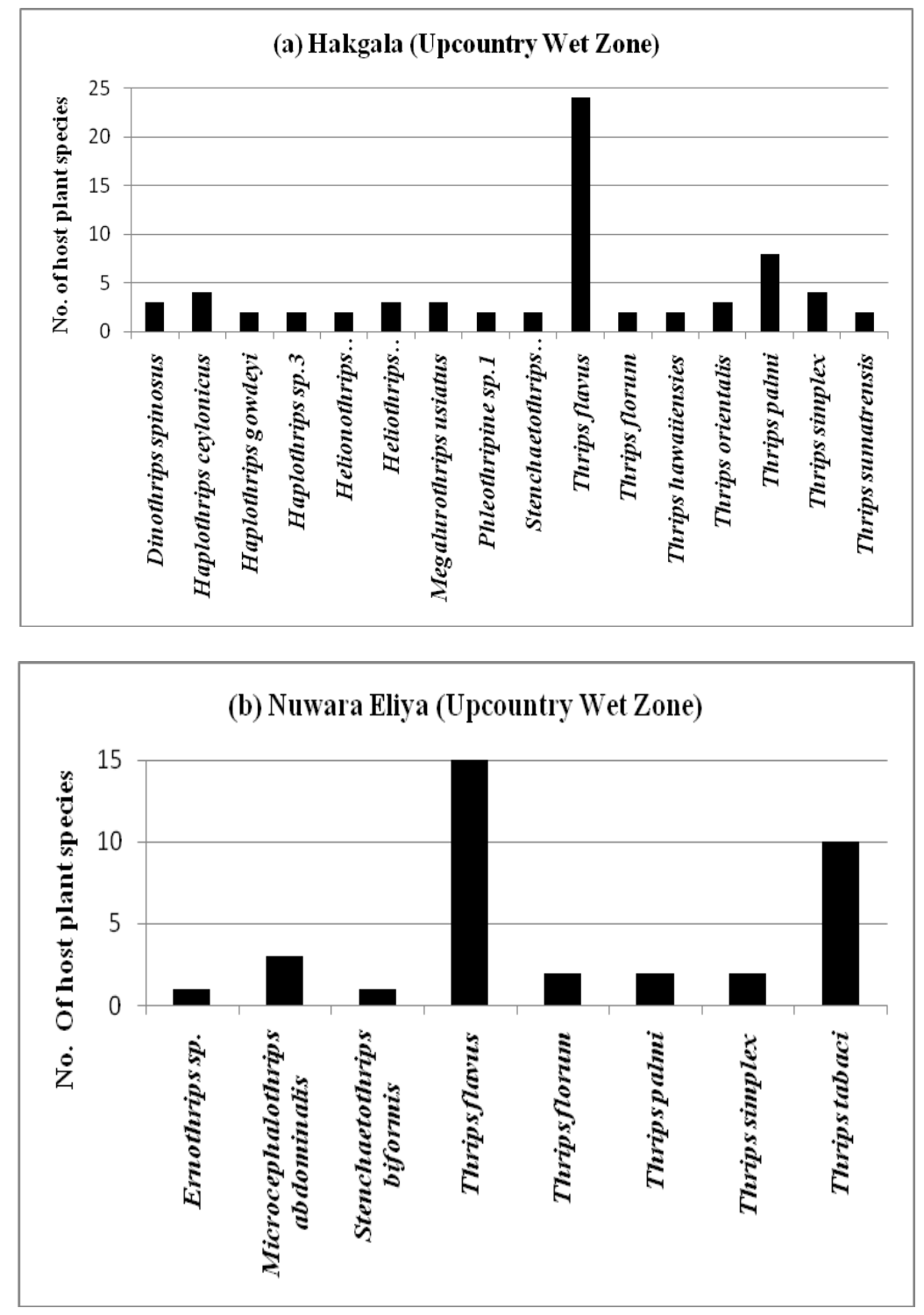
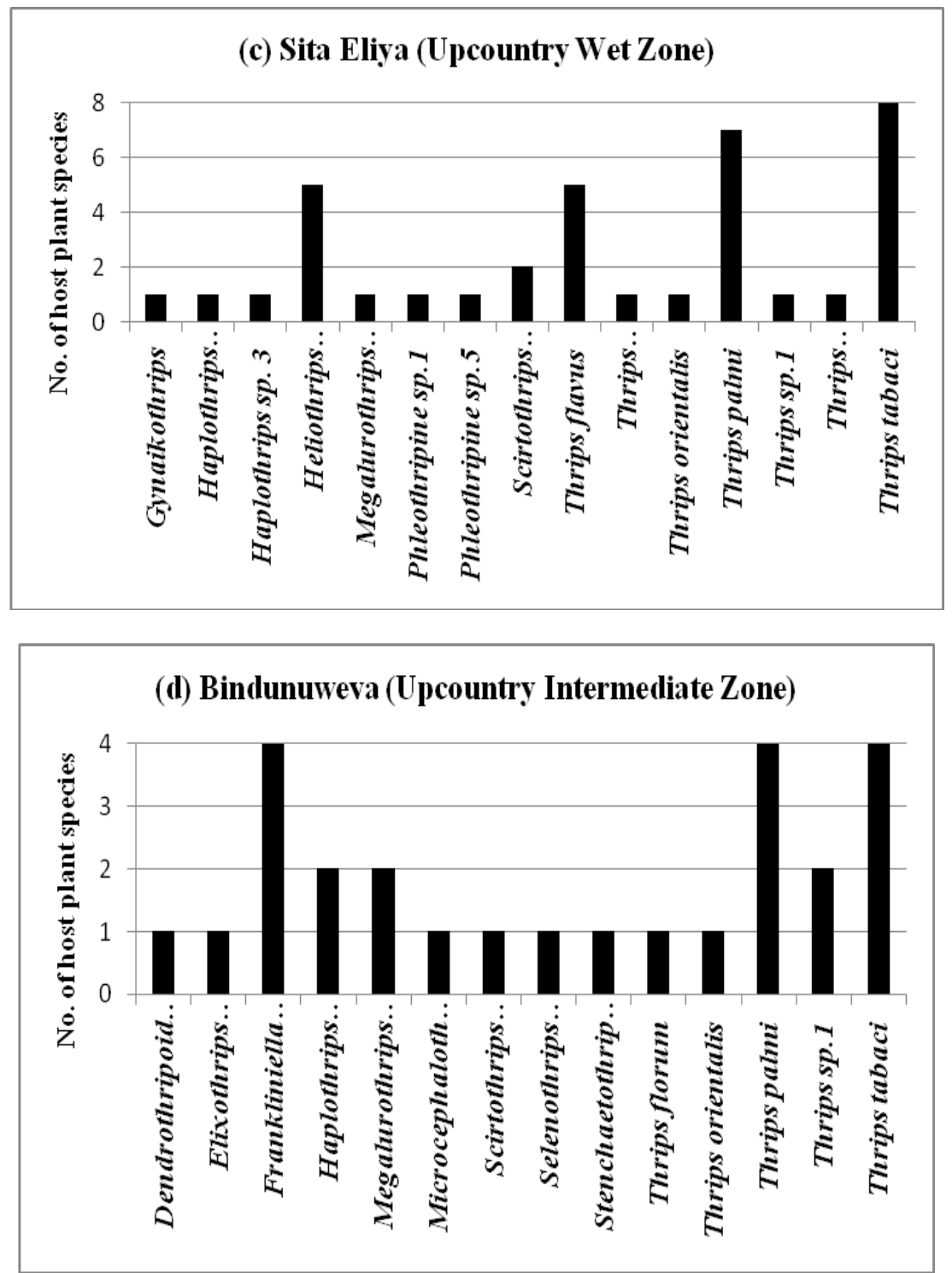

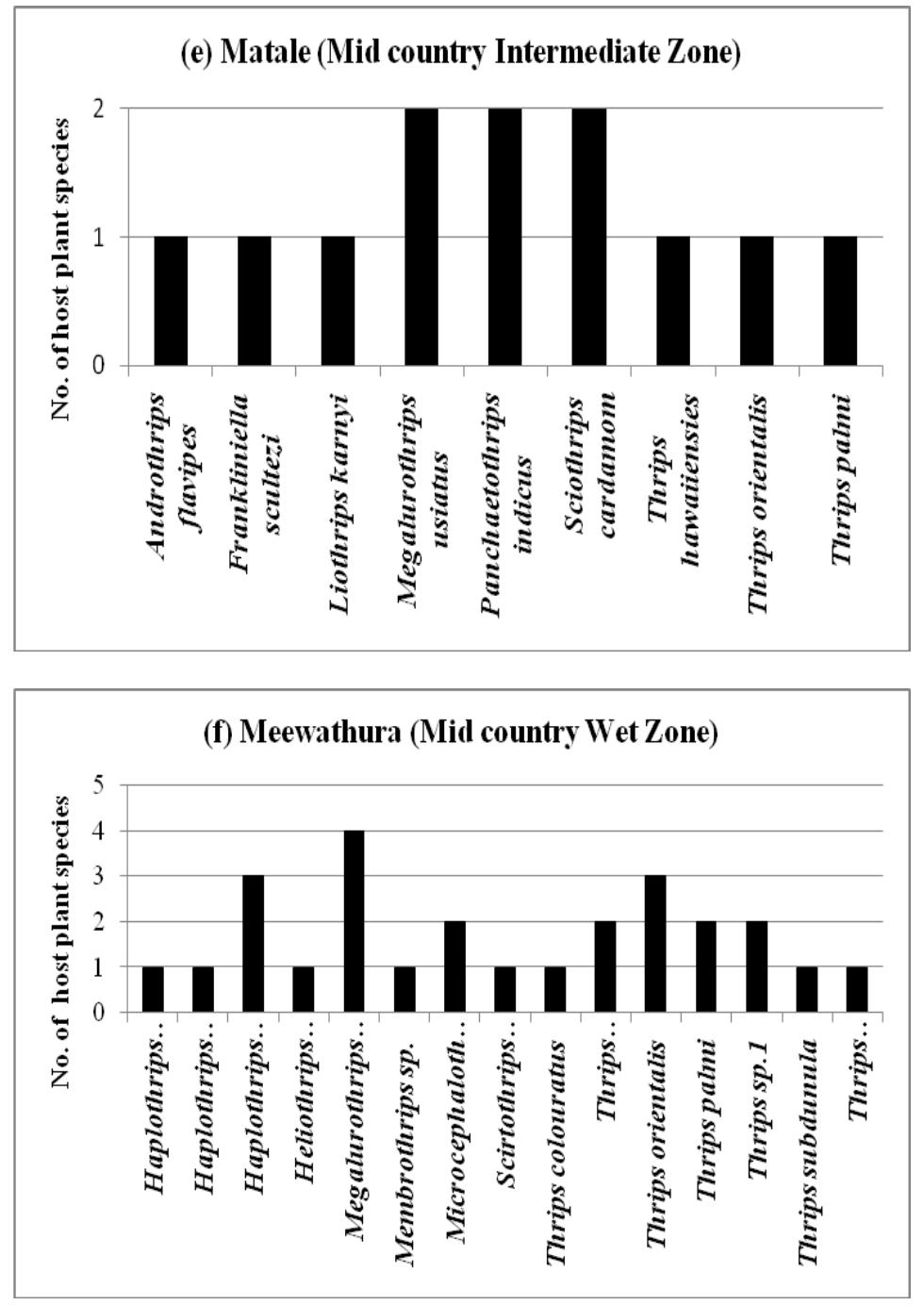
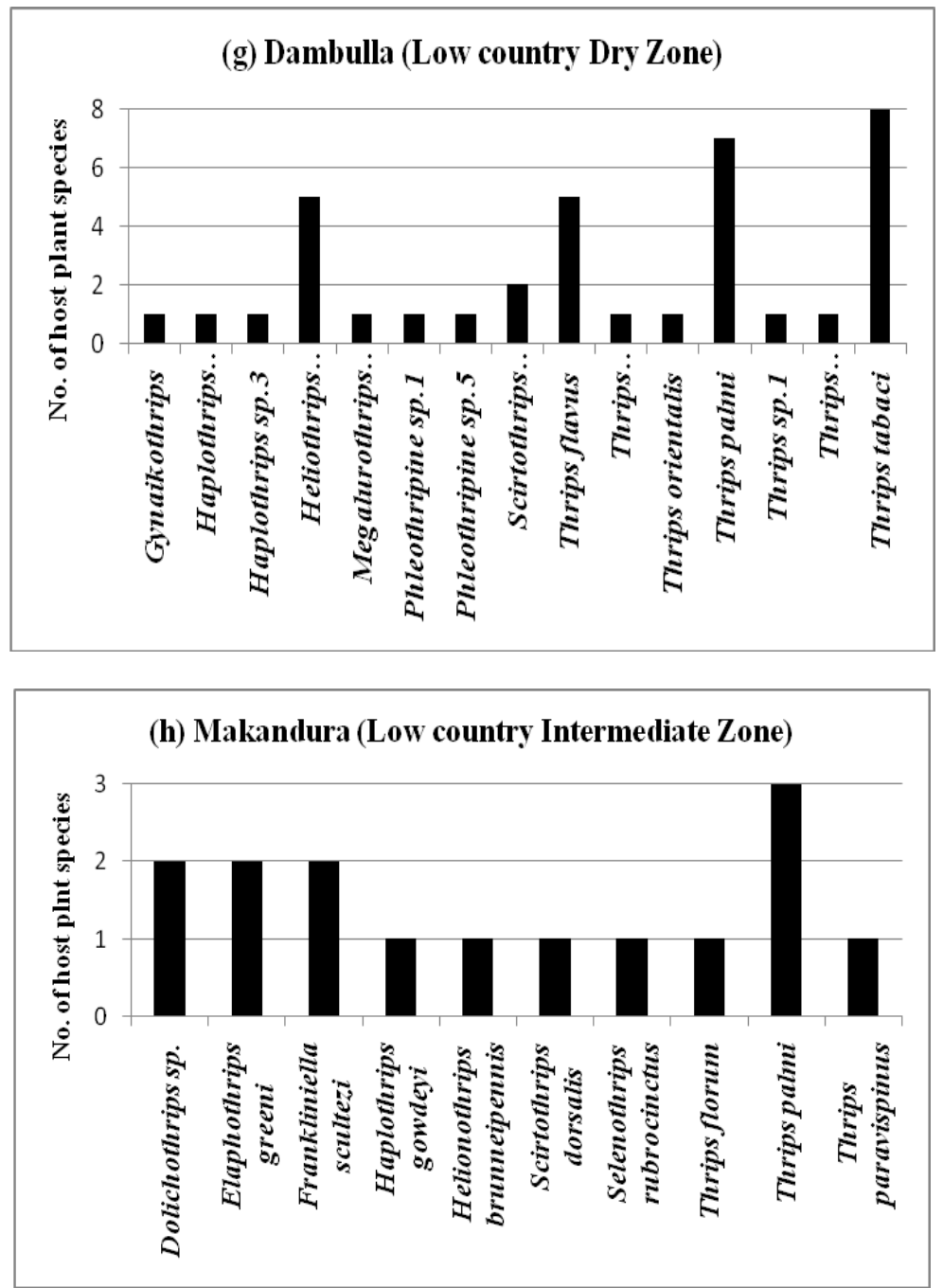
Haplothrips ganglbaueri had the widest host range (49 spp.) present in Poaceae and Cyperaceae and similarly, Anaphothrips sudanensis was confined to a few grasses (3 spp.). From Poaceae was also recorded Arorathrips mexicanus. Other thrips species specific to certain plant families were: Megalurothrips usitatus and Ayyaria chaetophora to Fabaceae, Sphingothrips trachypogon to Ebenaceae, Thrips simplex to Iridaceae and Microcephalothrips abdominalis to Asteraceae. Genus Thrips had a wide host range infesting diverse families and genera of plants. Thrips flavus, T. florum, T. hawaiiensis and T. palmi in particular were recorded from over 40 host plant species and are the most polyphagous thrips species.

Leaf litter samples yielded mostly larval stages of thrips making identification difficult and in several samples none were found. The leaf litter dwelling thrips recorded were fungal feeding Apelaunothrips sp. and the predatory Karnyothrips melaleucus.

\section{Thrips damage}

Different types of feeding damages were observed in thrips infested plants. Silvering, browning and discolouration of flowers and leaves were the most common types of damage observed. Certain species caused leaf deformity and/or premature flower fall. Thrips responsible for such damage belonged to the genera Frankliniella and Thrips. Thrips hawaiiensis caused premature flower loss. Infestations by Scirtothrips dorsalis caused young leaves of plants to curl and turn yellow. Gall formation was not so common in crops, but thrips in the family Phlaeothripidae produced leaf galls, particularly in Ficus spp. Feeding by Gynaikothrips ficorum, Gigantothrips tibialis and Liothrips karnyi resulted in leaf galls (Fig. 4). Androthrips flavipes infesting Piper, is considered a predator of gall iducing thrips. Bronzing in leaves was yet another type of damage observed in thrips infested plants; five species, Ayyaria chaetophora, Dendrothripoides Dendrithrips innoxius, Pseudodendrothrips ornatissimus, Scirtothrips dorsalis and Thrips palmi were responsible for this damage.

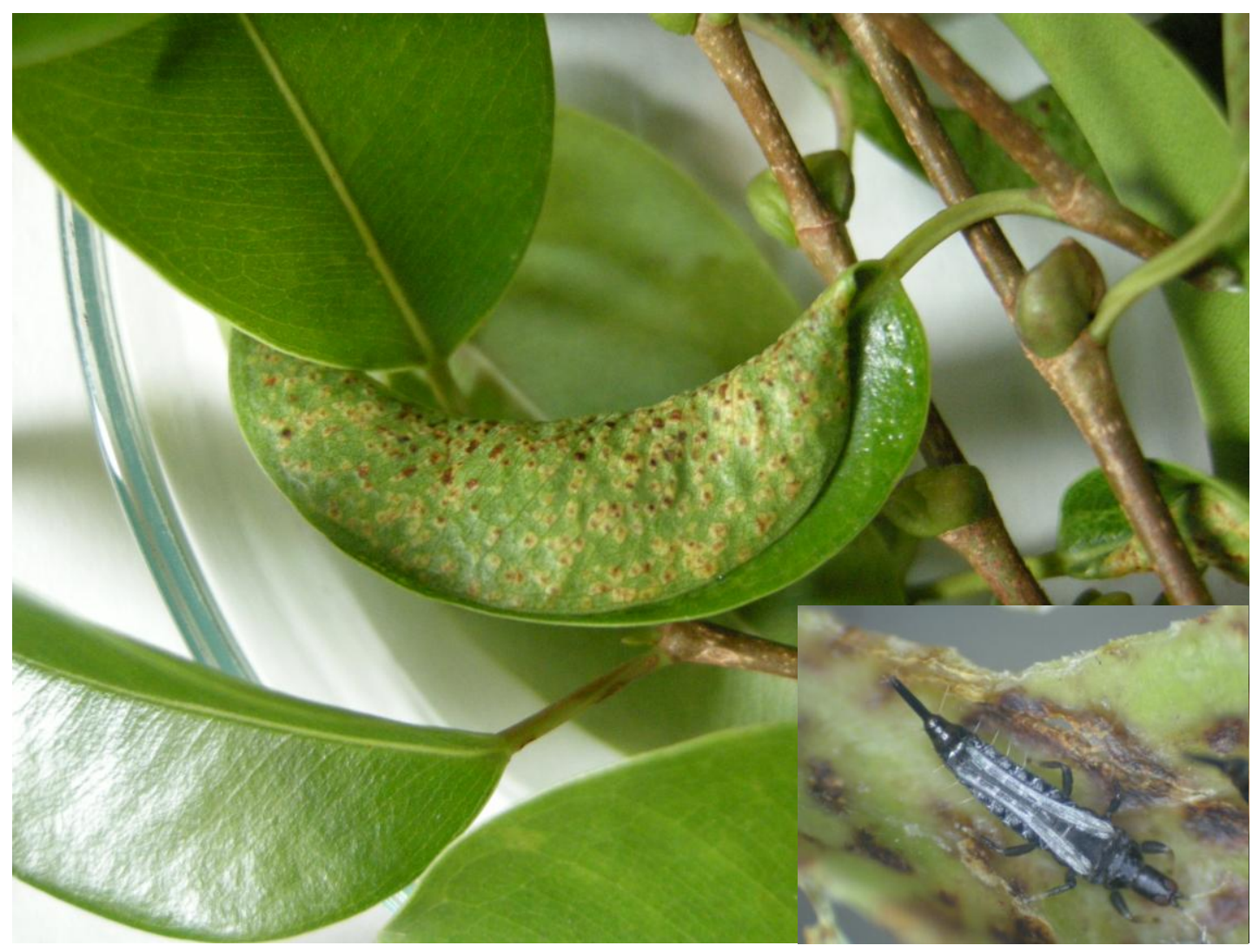

Figure 4. Leaf fold damge in Ficus bengamina due to infestation by Gynaikothrips ficorum (Inset). 


\section{DISCUSSION}

The survey represents the very first comprehensive collection of thrips from different habitats and regions in selected locations of Sri Lanka. It also enabled updating previous thrips records and their host plants, since the initial work on thrips in Sri Lanka by Schmutz (1913) and a few studies thereafter. A large number of the newly recorded and previously recorded thrips species being pests of cosmopolitan distribution is of concern. A likely factor that may be responsible for their spread is the cut flower and foliage trade that operates across trans-boundaries, which have become important export commodities in the developing and developed world. The degree to which pest species of thrips are emerging can only be estimated if baseline information is available on existing species in a country. This study attempted to fulfill this task through collections made in selected locations.

The number of thrips species recorded through the survey is relatively small in comparison to the fauna of neighbouring India where 625 species have been reported (Ananthakrishnan and Muraleeedharan, 1974). The 24 species recorded for the first time in Sri Lanka also occur in India. Furthermore, of the recorded thrips, 53 species in 41 genera are shared with India. However, Thrips parvispinus recorded during this survey is not represented in India (Ananthakrishnan \& Sen, 1980; Bhatti, 1990).

Although, the survey documented host plants and localities of the 72 species of thrips, no specific association between them was evident. Hence, no clear pattern of distribution in relation to host plants of the thrips was recognized. It is hoped that this survey would be an impetus for more intensive collections islandwide with the emphasis on agricultural and floricultural areas.

Symptoms of viral infection in thrips infested plants are often difficult to detect, as plants with nutrient deficiencies too tend to show similar symptoms. Therefore, without detailed investigations it is not correct to confirm viral symptoms. Tospoviruses are considered to depend on thrips for their existence in nature. Only $9(0.2 \%)$ of the 5,500 known species of thrips have been shown to be associated with viral diseases (Mound, 1996). During the survey although 5 potential viral vector species were recorded, symptoms of viral disease was not observed.

In the subfamily Phlaeothripinae about 300 species are known to induce galls on nearly 300 angiosperm species (Raman and
Ananthakrishnan, 1984). Galls of four main morphotypes are induced by thrips. They are leaf fold galls, leaf rolled galls, ceratoneon pouch galls, axillary bud galls and convoluted leaf galls (Lewis, 1973, Ananthakrishna \& Raman, 1989). Of them, leaf fold galls, leaf rolled galls and convoluted leaf galls were observed in plants (Appendix 1) infested by 5 thrips species in the subfamily Phlaeothripinae. Most thrips induced galls were infested with one or more secondary thrips species. But they are relatively fewer than the gall making thrips. Androthrips flavipes recorded on Piper nigrum was one such species of predatory thrips of gall forming thrips.

Of the 180 pest thrips of the world (Moritz et al., 2001), 14 were recorded from vegetable crops during the study. Majority of the thrips species infesting vegetables were specific to the crop host rather than to the habitat or location. Leaf curl in chilli was widespread whenever infestations of Scirtothrips dorsalis were present as evident from previous work in Sri Lanka by Gunawardena (2002) and the world (Edwards and Dixon, 2005). Host records of thrips and their damage reported from vegetable crops in this study agree well with findings made in other countries (Moritz et al., 2004), inferring the cosmopolitan nature of their distribution in relation to common vegetable crops of the world.

There is a paucity of published information on thrips damage to cut flowers in Sri Lanka. According to Halstead et al. (2000) in USA, the major pest thrips of rose, asters and chrysanthemum is Frankliniella occidentalis, the Western Flower Thrips. This species had been previously recorded from Sri Lanka on other plant hosts and not from cut flowers. The thrips species on gladiolus and anthuriums are very specific to their host and are found in all parts of the world where these plants are grown. In countries where gerberas are grown, heavy infestations of thrips have been reported (Spiers et al., 2008), while in Sri Lanka the damage appears minimal with only small populations of thrips being recorded. It is important to conduct regular islandwide surveys of thrips to track the spread of thrips species, especially the pest species and new introductions into an island nation across trans-boundaries.

\section{ACKNOWLEGEMENTS}

It is through the support of many individuals and institutions that this study was made possible. Deputy Directors of Regional Agricultural Research Stations in Sita Eliya (Dr. Mangalika 
Nugaliyadde), Angunukolapelessa, Bathalagoda, Bandarawela, Maha Iluppallama, Makandura and Gannoruwa (Ms. I. Wahundeniya); Director, Royal Botanical Gardens and Deputy Director of the Hakgala Botanical Gardens supported us in collecting thrips from their respective areas. Agricultural Extension Officer at Nuwara Eliya helped in collecting thrips from cut flower farms and parks and Ms. Dayani Karunanayake of Horticultural Research Development Institute (HORDI) provided thrips found on anthuriums. It is with the ready help of Dr. L. A. Mound, Honourary Research Fellow, CSIRO, Entomology Australia and Prof. J.S. Bhatti, New Delhi, India that the identity of difficult thrips specimens and the newly recorded species for Sri Lanka were confirmed. The staff of the National Herbarium, Peradeniya and Dr. Asanga Weearatunge, formerly of the Dept. of Botany, University of Peradeniya helped with the identification of plant specimens. Ms. Shanthi Dharmaratne of the Dept. of Zoology assisted with slide mounting of specimens and also provided specimens from her collection. Mr. Niroshan Samarasinghe is acknowledged for the photography. Mr. Dileepa Wattegama assisted us with field work. Permission was granted by the Forest Department and the Department of Wildlife Conservation to collect specimens and to send selected thrips specimens abroad for confirmation of their identity. The study was made possible through funding from the National Science Foundation of Sri Lanka (Grant No.RG/2005/EB/05)

\section{REFERENCES}

Ananthakrishnan, T.N. and Muraleedharan, N. (1974). Studies on the GynaikothripsLiophlaeothrips-Liothrips complex from India. Oriental Insects, Supplement, No. 4: $1-85$.

Ananthakrishnan, T. N. and Raman, A. (1989). Thrips and gall dynamics. Leiden Brill. Pp.120.

Ananthakrishnan, T.N. and Sen S. (1980). Taxonomy of Indian Thysanoptera. Zoological Survey of India (Handbook Series) 1: 1-234.

Bhatti, J.S. (1979a). A revised classification of Thysanoptera (Abstract). Workshop on Advances in Insect Taxonomy in India and the Orient, Manali (H.P.), October 9-12, Pp. 4648. Delhi. (Abstract).

Bhatti, J.S. (1979b). A Review of Oriental Thripidae (Thysanoptera). Workshop on Advances in Insect Taxonomy in India and the Orient, Manali (H.P.), Pp. 81. (Abstract)
Bhatti, J.S. (1986). A new species of Holarthrothrips from Iraq, with notes on host plants and key to species, along with clarification of the position of this genus among Thysanoptera. Zoology 1(1): 1-33.

Bhatti, J.S. (1988). The orders Terebrantia and Tubulifera of the superorder Thysanoptera (Insecta). A Critical Appraisal. Zoology 1(2): 167-240.

Bhatti, J.S. (1989). The classification of Thysanoptera into families. Zoology 2(1): 123.

Bhatti, J. S. (1990). Catalogue of Insects of the Order Terebrantia from the Indian subregion. Zoology 2 (4): 205-352.

Bhatti, J.S. (1994). Phylogenetic relationships among Thysanoptera (Insecta), with particular reference to the families of the Order Tubulifera. Zoology 4: 93-130.

Bhatti, J.S. 2003. Some newly recognized characters of the Order Tubulifera representing highly conserved character states. Thrips No. 2. Thysanoptera: 41-48.

Bhatti, J.S. (2004a). T.N. Ananthakrishnan's entomological publications between 1947 and 2004. Bibliography with annotations. Thrips No. 3. Thysanoptera (No.1): 1-84.

Bhatti, J.S. (2004b). T.N. Ananthakrishnan's taxa of Thysanoptera 1950 to 1980. Thrips No. 4. Thysanoptera (No.2): 85-181.

Bhatti, J.S. (2006). The classification of Terebrantia (Insecta) into families. Oriental Insects 40: 339-375.

Edwards, G.B. and Dixon, W. (2005). Chilli thrips Scirtothrips dorsalis Hood (Thysanoptera: Thripidae). A new pest thrips for Florida. Florida Department of Agriculture and Consumer services division of Plant Industry. (http://www.doacs.state.fl.us/pi/ enpp/ento/chillithrips.html).

Gunawardena, K.N.C. (2002). Assessment of yield loss due to thrips (Thysanoptera: Thripidae) in chilli. Annals of the Sri Lanka Department of Agriculture 4:275-280.

Halstead, A., Chase, A. R. and Gilrein, D. (2000). Pest and Disease: The Complete Guide to Preventing, Identifying Treating Plant Problems. American Horticultural Association. Pp. 224.

Hoddle, M.S., Oevering, P., Phillips, P.A. and Faber, B. A. (2004). Evaluation of augmentative release of Franklinothrips orizabensis for control of Scirtothrips persea in California avocado orchards. Biological Control 30: 456- 465.

Lewis, T. (1973). Thrips, Their Biology, Ecology and Economic Importance. Academic Press, London and New York. 349 Pp. 
Moritz, G., Mound, L.A., Morris, D.C. and Goldarazena, A. (2004). Pest thrips of the world: CD-Rom. Brisbane: Cent. Biol. Inf. Technol .

Moritz, G., Morris, D.C. and Mound, L.A. (2001). Thrips ID - Pest Thrips of the World. CD-Rom Published for ACIAR by CSIRO Publishing, Melbourne.

Morse J.G. and Hoddle M.S. (2006). Invasion biology of thrips. Annual Review of Entomology 51: 67-89.

Mound L.A. (1996). The Thysanoptera vector species of tospoviruses. Acta Horticulturae. 431: 298-309.

Mound, L.A and Kibby, G (1998) Thysanoptera: An identification guide. CAB International, Oxford, UK. Pp.70.

Mound, L.A. (2004). Thysanoptera - Diversity and Interactions. Annual Review of Entomology 50: 247-269.

Mound, L.A. and Reynaud, P. (2005). Franklinothrips: A pantropical Thysanoptera genus of ant-mimicking obligate predators (Aeolothripidae). Zootaxa 864: 1-16.

Mound, L.A., Hemming, B.S. and Palmer J.M. (1980) Phylogenetic relationships between the families of recent Thysanoptera. Zoological Journal of Linnean Society of London 69: 111141.

Mound, L.A. and Palmer, J.M. (1983). The generic and tribal classification of sporefeeding Thysanoptera (Phlaeothripidae: Idolothripinae). Bulletin of the British Museum Natural History). Entomology 46: 1-174.

Nyree, J.C.Zerega., Mound, Laurence A. and Weiblen, George D. (2004). Pollination in the New Guinea endemic Antiaropis decipiens (Moraceae) is mediated by a new species of thrips, Thrips antiaropsidis sp.nov. (Thysanoptera: Thripidae) International Journal of Plant Sciences 165 (6):1017-1026.

Oda,Y., Kahawatta, U.C., Rajapaksha, P. and Rajapaksha, H. (1997). Thrips collected in Sri Lanka. Research Bulletin of the Plant Protection Service, Japan 33: 71-73.
Palmer, J.M. (1980). Identification of the common thrips of tropical Africa. (Thysanoptera: Insecta). Tropical Pest Management 36 (1): 27 -29.

Palmer, J.M. and Mound, L.A. (1978) Nine genera of fungus-feeding Phlaeothripidae (Thysanoptera) from the Oriental Region. Bull. Br. Nat. Hist. (Entomol.) 37:153-215.

Pitkin, B.R. (1976). A revision of the Indian species of Haplothrips and related genera (Thysanoptera: Phlaeothripidae). Bull. Brit. Mus. Nat. Hist . (Entomol.) 34(4): 223-280.

Priesner, H. (1949) Genera Thysanopterorum. Bulletin de la Societe Fouad $I^{e r} d$ ' Entomologie 33: 34-157

Raman A. and Ananthakrishnan T.N. (1984). Biology of gall thrips (Thysanoptera: Insecta). In. T.N. Ananthakrishnan (Ed.) Gall Insects. Oxford Publishing Co.New Delhi. Pp.107127.

Schmutz, K. (1913). Zur Kentniss der Thysanopterenfauna von Ceylon. Sitzungsber. Akad. Wiss. Wien 122: 991-1089.

Spiers, J.D., Davies, F.T, Jr., Heinz, K.M., Bogran, C.E and Starman, T.W. (2008). Do insecticides affect plant growth and development? (http://www.grenhouegrower. com).

Syed, R.A. (1979) Studies on oil palm pollination by insects. Bulletin of Entomological Research 69: 213-224.

Tillekaratne, K., Mound, L. A., zur Strassen, R. and Edirisinghe, J.P. (2007). List of thrips (Thysanaptera) recorded from Sri Lanka. Journal of the National Science Foundation, Sri Lanka 35 (3): 197-205.

Wijerathna, P.M. (1999). Insects feeding on plants in Sri Lanka. Plant Genetic Resource Center, Gannoruwa, Peradeniya. Pp.171.

Wilson, T.H. (1975). A monograph of the subfamily Panchaetothripinae (Thysanoptera: Thripidae). Memoirs of the American Entomological Institute 23: 1-354. 
Appendix 1. Systematic list of Thysanoptera ${ }^{1}$ recorded during the survey with details of distribution, host records, and damage.

\section{SUBORDER TEREBRANTIA ${ }^{2}$}

\section{Family Thripidae $^{3}-$ Subfamily Panchaetothripinae $^{4}$}

1. $* * \uparrow$ Astrothrips tumiceps Karny 1923 - Angunakolapellassa Dacus carota L. (Apiaceae), Elusine indica (L.) Gaertn. (Poaceae).

2. $\nmid$ Caliothrips indicus (Bagnall 1913) - Maha-Illuppallama \& Peradeniya Leaves of grasses (Poaceae).

3. *Caliothrips luckmanni Willson 1975 - Angunakolapelassa Achyranthes aspera L. (Amaranthaceae).

Damage: Brown and white marks on leaves.

4. ** †Elixothrips brevisetis Bagnall 1919 - Peradeniya Clerodendrum infortunatum L. (Verbenaceae).

5. Helionothrips brunneipennis (Bagnall 1915) - Makandura and Peradeniya Litsea glutinousa (Lauraceae), Michelia nilagirica Zenker (Magnoliaceae), Neolitsea cassia (Lauraceae).

Damage: Scarring and browning of leaves and the whole plant becomes severely affected.

6. $†$ Heliothrips haemorrhoidalis (Bouché 1833) (Green house thrips) - Gannoruwa, Hakgala, Sita Eliya, Meewathura and Kahagolla

Annona muricata L.(Annonaceae), Averrhoa carambola L.(Oxalidaceae), Elaeocarpus montanus Thw. (Elaeocarpaceae), Euodia lunu-ankenda (Gaertn.) Merr. (Rutaceae), Glochidion pycnocarpum (Muell.Arg.) Bedd. (Euphorbiaceae), Gossypium arboreum L. (Malvaceae), Pelargonium graveolens L'Hérit. (Geraniaceae), Persea americana Miller (Lauraceae), Ternstroemia gymnathera (Wight \& Arn.) Beddome (Theaceae).

Damage: Scaring and browning of leaves and buds.

\footnotetext{
${ }^{1}$ Thysanoptera, conventionally treated as an insect order, have been considered as superorder (Bhatti 1986, 1988, 1994, 2003) to include two orders Terebrantia and Tubulifera, which have been treated by other authors as suborders of order Thysanoptera.

2 Since 1979 (Bhatti 1979a, Mound et al. 1980) the Terebrantia had been divided into 7 families: Uzelothripidae, Merothripidae, Aeolothripidae, Stenurothripidae / Adiheterothripidae, Thripidae, Hemithripidae / Fauriellidae, and Heterothripidae, included in 4 superfamilies: Uzelothripoide, Merothripoidea, Aeolothripoidea, Thripoidea (Bhatti 1979a). An eighth family Melanthripidae was added (Bhatti 1990) under Aeolothripoidea.

More recently, the Terebrantia have been classified into 10 superfamilies comprising 28 families (Bhatti 2006).

${ }^{3}$ Following Priesner (1949), the family Thripidae was divided into two subfamilies Thripinae and Panchaetothripinae, until Bhatti (1979b, 1989) recognized four subfamilies under Thripidae. Subsequently (Bhatti 2006) members of Thripidae were classified into 12 different families in 10 superfamilies based essentially on previously unknown structural features.

${ }^{4}$ The genera of Panchaetothripinae in the present list are included in six different families under three superfamilies in Bhatti (2006). Dendrothripoidea (Retithripidae: Retithrips), Rhipiphorothripoidea (Rhipiphorothripidae: Rhipiphorothrips), Thripoidea (Caliothripidae: Caliothrips. Heliothripidae: Elixothrips, Helionothrips, Heliothrips, Oneilliella, Selenothrips. Panchaetothripidae: Panchaetothrips. Tryphactothripidae: Astrothrips, Tryphactothrips).
} 
7. $\uparrow$ Panchaetothrips indicus Bagnall 1912 - Matale and Angunakolapellassa Alpinia calcarata Roscoe (Zingiberaceae), Curcuma longa L. (Zingiberaceae), Elettaria cardamomum (L.) Maton (Zingiberaceae).

Damage: white streaks and patches on leaves.

8. $†$ Retithrips syriacus Mayet 1890 (Castor thrips)- Angunakolapellassa and Maha- Illuppallama Gossypium arboreum L. (Malvaceae), Rosa indica L. (Rosaceae), Ricinus communis L. (Euphorbiaceae), Tinospora cordifolia (Wild.) Hook. f. \& Thoms. (Menispermaceae), Terminalia arjuna (Roxb.)Wight \& Arn.( Combretaceae), Vitis vinifera L. (Xyridaceae).

Damage: cloudy scarring, browning patches and discolouration in leaves.

9. Rhipiphorothrips pullchellus (Morgan 1913) - Peradeniya and Sinharaja forest Clerodendrum tomentosum R.Br.( Verbenaceae), Clitoria guianensis var. guianensis (Aubl.)Benth. (Fabaceae), Cissus trilobata Lam.(Vitaceae), Lagerstroemia speciosa (L.) Pers (Lythraceae).

10. $†$ Selenothrips rubrocinctus (Giard 1901) -Red banded thrips - Angunakolapellassa, MahaIlluppallama, Makandura, Kahagolla and Bindunuwewa Annona reticulata L. (Annonaceae), Nephelium lappaceum L. (Sapindacaeae), Vitis vinifera L. (Xyridaceae), Lactuc sativa L. (Asteraceae).

11. Tryphactothrips rutherfordi (Bagnall 1915) - Peradeniya Nauclea orientalis (L.) L (Rubiaceae), Passiflora edulis Sims. (Passifloraceae) Michelia champaca L. (Magnoliaceae).

12. **Oneilliella sp. - Peradeniya. Clerodendrum infortunatum L. (Verbenaceae).

\section{Family Thripidae - Subfamily Dendrothripinae ${ }^{5}$}

13. $\uparrow$ Pseudodendrothrips ornatissimus Schmutz 1913 - All climatic zones Artocarpus heterophyllus Lam. (Moraceae). Damage: Brown patches on leaves.

14. †Dendrothrips sexmaculatus Bagnall 1916 - Peradeniya Flacourtia jangomas (Lour.) Rausch. (Flacourtiaceae).

\section{Family Thripidae - Subfamily Thripinae}

15. †Anaphothrips sudanensis Trybom 1911 - Bathalagoda, Kahagolla and Maha Illuppallma Eleusine coracana (L.), Elusine indica (L.) Gaertn. and Eragostis uniloides (Retz.) (Poaceae).

16. ** $\uparrow^{6}$ Arorathrips mexicanus Crawford 1909 - Dry zone and Intermediate zones Eleusine coracana (L.) Gaertn. (Poaceae), Eleusine indica (L.) Gaertn. (Poaceae), Sesamum indicum L. (Pedaliaceae), Chloris barbata Sw, (Poaceae), Dactyloctenium aegyptium (L.) Willd. (Poaceae), Hippeastrum puniceum (Lam.) Kuntze. (Amaryllidaceae), Coccinia grandis (L.) J. Voight (Cucurbitaceae).

\footnotetext{
${ }^{5}$ Included in family Dendrothripidae of superfamily Dendrothripoidea in Bhatti (2006).

${ }^{6}$ Included in family Chirothripidae of superfamily Thripoidea in Bhatti (2006).
} 
17. ** †Ayyaria chaetophora Karny 1927 - Kahagolla and Angunakolapellassa

Arachis hyphogaea L., Glycine max (L.) (Merr.), Phaseolus vulgaris L. Vigna radiata L.( Wilczek), Vigna unguiculata sesquipedalis (L.) Verdc. (Fabaceae), Tagetes erecta L. (Asteraceae), Ricinus communis L. (Euphorbiaceae).

18. ** †Ceratothripoides claratris (Shumsher 1946) - Angunakolapellassa and Maha Illuppallama. Capsicum annum L. (Solanaceae), Coccinia grandis (L.) J.Voight (Cucurbitaceae), Solanum trilobatum L. (Solanaceae), Solanum macrocarpon L. (Solanaceae).

19. $†$ Chaetanaphothrips orchidii Moulton 1907 - Peradeniya and Bandarawela Anthurium andraeanum Linden (Araceae)

Damage: White streaks on unopened flowers and leaves, discolouration of spathe.

20. $†$ Chaetanaphothrips signipennis Bagnall 1914 - Angunakolapelassa Musa paradisiaca L. (Musaceae).

21. ** $†$ Craspedothrips minor (Bagnall 1923) - Angunakolapellassa, Maha-Illuppallama, Kahagolla and Dambulla

Cassia occidentalis L. (Fabaceae), Gloriosa superba L. (Colchicaceae), Gmelina asiatica L. (Verbenaceae), Ricinus communis L. (Euphorbiaceae).

22. ** ${ }^{7}$ Dendrothripoides innoxius (Karny 1914) - Angunakolapelassa and Kahagolla Ipomoea batatas (L.) Lam. and Ipomoea indica (Burm.f.) Merr.(Convolvulaceae). Damage: Bronzing of leaves.

23. **Dichromothrips smithi (Zimmermann 1900) - Sinharaja forest Arundinia graminifolia (D.Don) Hochr (Orchidaceae).

24. **Ernothrips sp.- Kahagolla and Nuwara Eliya Hedyotis sp. (Rubiaceae), Hippeastrum puniceum (Lam.) Kuntze (Amaryllidaceae).

25. $†$ Frankliniella schultzei (Trybom 1910) - (Common blossom thrips) - all climatic zones Abelmoschus esculentus (L.) Moench Malvaceae), Andrographis paniculata (Burm.f.) Wall.ex Nees (Acanthaceae), Aporusa lindleyana (Wight)Baill. (Euphorbiaceae), Arachis hyphogaea L. (Fabaceae), Capsicum annum L.(Solanaceae), Dichrostachys cinerea (L.) Wight \& Arn. (Fabaceae), Gloriosa superba L. (Colchicaceae), Gmelina asiatica L. (Verbenaceae), Hibiscus vitifolius L. (Malvaceae), Zinnia sp., (Asteraceae), Impatiens repens Moon (Balsaminaceae), Ipomoea indica (Burm.f.) Merr. (Convolvulaceae), Ocimum basilicum L. (Lamiaceae), Osbeckia octandra (L.) DC. (Melastomataceae), Solanum macrocarpon L. (Solanaceae), Solanum violaceum Ortega.(Solanaceae), Thunbergia grandiflora (Roxb.ex Rottler) (Acanthaceae), Zinnia sp. (Asteraceae).

Damage: Scarring, browning and discolouration of flowers.

26. $\uparrow$ Frankliniella occidentalis (Pergande 1895) (Western flower thrips)

Angunakolapellassa, Bathalagoda, Maha- Illuppallama and Knuckles forest

Ageratum conyzoides L., (Asteraceae), Eichhornia crassipes (Mart.) Solms-Laub. (Pontederiaceae), Nelumbo nucifera Gaertn. (Nelumbonaceae), Solanum violaceum Ortega (Solanaceae).

Damage: Scarring, browning and discolouration of flowers.

27. $†$ Megalurothrips usitatus (Bagnall 1913) - All agroecological regions

Arachis hyphogaea L. (Fabaceae), Cajanus cajan (L.) Millsp.(Fabaceae), Cassia auriculata L. (Fabaceae), Cleome chelidonii L.f. (Capparaceae), Crotolaria juncea L. (Fabaceae), Crotolaria micans Link (Fabaceae), Crotolaria sp.1 (Fabaceae), Desmodium heterophyllum (Willd.)DC. (Fabaceae), Erythrina variegata L. (Fabaceae), Gliricidia sepium (Jacq.) Walp. (Fabaceae), Hiptage benghalensis (L.) Kurz (Malpighiaceae), Phaseolus lunatus L. (Fabaceae), Phaseolus vulgaris L. (Fabaceae), Pueraria phaseoloides (Roxb.)Benth. (Fabaceae), Sesbania grandiflora 
(L.) Poir. (Fabaceae), Vigna mungo (L.) (Fabaceae), Vigna unguiculata (L.) Walp. (Fabaceae), Vigna unguiculata sesquipedalis (L.) Verdc. (Fabaceae).

Damage: Scarring, browning and discolouration of flowers and buds.

\section{8. $†$ Microcephalothrips abdominalis (Crawford 1910) (Composite Thrips)}

All agroecological regions

Ageratum conyzoides L., Bellis perennis L., Bellis sp., Bidens pilosa L., Bidens sp., Callistephus chinensis (L.) Nees, Chrysanthemum segetum L., Coreopsis grandiflora Hogg ex Sweet, Cosmos sulphureus Cav., Dahlia hortensis, Emilia exserta Fosberg, Emilia speeseae Fosberg, Eregeron sublyratus DC., Euandatorium inulifolium HBK, Euphotorium odaratum L.Gerbera jamesonii Adlam, Helianthus annuus L., Heliopsis helianthoides (L.) Sweet, Mikania cordata (Burm.) (Asteraceae), Solidago canadensis L., Spilanthes calva DC, Spilanthes jabadicensis A.H.Moore, Tagetes erecta L, Tithonia diversifolia (Hemsl.) A.Gray, Tridax procumbens L., Wedelia chinensis (Osbeck) Merr. (Asteraceae).

Damage: Scarring, browning and discolouration of flowers.

29. ${ }^{7}$ Neohydatothrips samayunkur Kudô 1995 - (Marigold thrips) Bandarawela Tagetes erecta L (Asteraceae).

30. $* * \dagger$ Rhamphothrips pandens Sakimura 1983 - Knuckles forest, Kahagolla and Maha Illuppallama Cassia occidentalis L. (Fabaceae), Clerodendrum tomentosum R.Br. (Verbenaceae), Clitoria guianensis var. guianensis (Aubl.) Benth. (Fabaceae), Hibiscus vitifolius L. (Malvaceae), Lagerstroemia speciosa (L.) Pers (Lythraceae).

31. †Sciothrips cardamomi (Ramakrishna 1935) (Cardamom thrips) - Matale and Knuckles Region Elettaria cardamomum (L.)Maton (Zingiberaceae).

Damage: Streaking and wilting of cardamom leaves.

32. $\uparrow$ Scirtothrips dorsalis Hood 1919 (Chilli thrips )- All climatic zones Abelmoschus esculentus (L.) Moench (Malvaceae), Amaranthus spinosus L (Amaranthaceae), Capsicum frutescens L. (Solanaceae), Capsicum annum L. (Solanaceae), Citrus limon (L.) Burm. f. (Rutaceae), Dacus carota L. (Apiaceae), Diplocyclos palmatus (L.) C. Jeffrey (Cucurbitaceae), Elettaria cardamomum (L.) Maton (Zingiberaceae), Euodia lunu-ankenda (Gaertn.) Merr. (Rutaceae), Fragaria vesca L. (Rosaceae), Limonia acidissima L. (Rutaceae), Mangifera indica (L.) (Anacardiaceae), Monodora myristica (Gaertn.) Dunal (Annonaceae), Psidium guajava L. (Myrtaceae), Punica granatum L. (Punicaceae), Rosa indica L. (Rosaceae), Solanum tuberosum L. (Solanaceae), Spondias cytherea Sonn. (Anacardiaceae).

Damage: Curling of leaves, bronzing and deformity of leaves.

33. $\uparrow$ Stenchaetothrips biformis (Bagnall 1913) (Rice thrips)-Bathalagoda, Maha Illuppallma and Knuckles region

Oryza sativa L. (Poaceae).

Damage: Streaking of leaves and wilting of seedlings.

34. $\uparrow$ Thrips coloratus Schmutz 1913 - Meewathura and Knuckles forest Mangifera indica (L.) (Anacardiaceae), Eupatorium odaratum L. (Asteraceae).

35. †Thrips flavus Schrank 1776 - Wide spread in Upcountry Wet zone

Agapanthus umbellatus L'Hérit.(Agapanthaceae), Alstroemeria sp. (Alstroemeriaceae), Amaryllis belladonna L. (Liliaceae), Azalea japonica Gray (Ericaceae), Brugmansia suaveolens (Humb. \& Bonpl. Ex Willd.) (Bercht.\& Presl.) Solanaceae, Caliandra surinemensis Benth. (Fabaceae), Calicarpa sp. (Verbenaceae), Callistephus chinensis (L.) Nees (Asteraceae), Canna generalis L. (Cannaceae), Cestrum elegans (Brongn.) Schlecht. (Solanaceae), Chrysanthemum segetum L. (Asteraceae), Clerodendrum serratum (L.) Moon (Verbenaceae), Eupatorium sp. (Asteraceae),

\footnotetext{
${ }^{7}$ Included in family Sericothripidae of superfamily Thripoidea in Bhatti (2006).
} 
Gerbera sp. (Asteraceae), Gladiolus sp. (Iridaceae), Hydrangea macrophylla (Thunb.) Ser. (Hydrangeaceae), Impatiens hawkeri Bull. (Balsaminaceae), Lilium candidum L. (Liliaceae), Limonium sp. (Plumbaginaceae), Lobularia maritima (L.) Desv. (Brassicaceae), Lupinus sp. (Fabaceae), Miconia calvescens DC. (Melastomataceae), Monodora myristica (Gaertn.) Dunal (Annonaceae), Ornithogalum thyrsoides Jacq. (Hyacinthaceae), Petunia x hybrida (Solanaceae), Phlox amoena Sims. (Polemoniaceae), Pyrus communis L. (Rosaceae), Rosa indica L. (Rosaceae), Spiraea cantoniensis Lour. (Rosaceae), Xerochrysum bracteata (Vent.)Tzvelev. (Asteraceae), Zantedeschia aethiopica (L.) Spreng. (Araceae).

Damage: Scarring, browning and discolouration of flowers.

36. $\uparrow$ Thrips florum Schmutz 1913 - Wet and Intermediate zones

Acacia pennata (L.) Wild. (Fabaceae), Aleurites montana (Lour.) E. Wilson (Euphorbiaceae), Amherstia nobilis Wall. (Fabaceae), Brunsfelsia latifolia Benth. (Solanaceae), Callistephus chinensis (L.) Nees (Asteraceae), Canna generalis L. (Cannaceae), Cassia didymobotrya Fresen. (Fabaceae), Celosia argentia L (Amaranthaceae), Citrus grandis (L.) Osbeck. (Rutaceae), Citrus medica L.(Rutaceae), Clerodendrum splendens G.Don ex James (Verbenaceae), Coccinia grandis (L.) J.Voight (Cucurbitaceae), Coffea arabica L. (Rubiaceae), Couroupita surinamensis Mart.ex O. Berg (Lecythidaceae), Crotolaria pallida Ait. (Fabaceae), Gardenia jasminoides J.Ellis (Rubiaceae), Gloriosa superba L. (Verbenaceae), Hedyotis fruticosa L. (Rubiaceae), Helicteres isora L. (Sterculiaceae), Hibiscus rosa-sinensis L.(Malvaceae), Hydrangea macrophylla (Thunb.) Ser. (Hydrangeaceae), Ipomoea indica (Burm.f.) Merr. (Convolvulaceae), Lantana camera L. (Verbenaceae), Leea indica (Burm.f.)Merr. (Leeaceae), Lilium candidum L. (Liliaceae), Lobularia maritima (L.) Desv (Brassicaceae), Ludwigia peruviana(L.)Hara (Onagraceae), Moringa oleifera Lam. (Moringaceae), Pentas lanciolata coccinea (Rubiaceae), Saraca asoca (Roxb.) Wilde (Fabaceae), Spathiphyllum sp. (Araceae), Spathodea campanulata Beauv. (Bignoniaceae), Tabebuia serratifolia (Vahl) Nicholson, Tecoma stans (L.) Kunth (Bignoniaceae), Thevetia peruviana (Pers.) Merr. (Apocynaceae), Urena lobata L. (Malvaceae).

37. $\uparrow$ Thrips hawaiiensis (Morgan 1913) - Wet and Intermediate zones

Brunfelsia latifolia Benth. (Solanaceae), Camellia sinensis (L.) kuntze (Theaceae), Canna generalis L(Cannaceae) Chrysanthemum segetum L.(Asteraceae), Citrus grandis (L.) Osbeck. (Rutaceae), Citrus limon (L.) Burm.f. (Rutaceae), Citrus medica L. (Rutaceae), Citrus megaloxylocarpa var. pennivesculata Lush. (Rutaceae), Citrus reticulata Blanco (Rutaceae), Cleome chelidonii L.f. (Capparaceae), Euphatorium sp. (Asteraceae), Gardenia jasminoides J. Ellis (Rubiaceae), Impatiens balsamina L. (Balsaminaceae), Malvaviscus penduliflorus Mocino. \& Sesse. Ex. DC. (Malvaceae), Mangifera indica (L.), (Anacardiaceae), Melilotus indicus (L.) All. (Fabaceae), Muntingia calabura L. (Tiliaceae), Musa paradisiaca L. (Musaceae), Persea americana Miller (Lauraceae), Pseudocalymma alliaceum (Lam.) Sandwith (Bignoniaceae), Psidium guajava L. (Myrtaceae), Rosa indica L. (Rosaceae), Saraca thaipingensis Prain (Fabaceae), Sarca asoca (Roxb.) de Wild (Fabaceae), Syzigium sp. (Myrtaceae),Ocimum tenuiflorum L. (Lamiaceae).

Damage: Scarring, browning and discolouration of flowers.

38. *Thrips levatus Bhatti 1980 - Peradeniya

Napoleona imperialis Pal de Beauv. (Lecythidaceae).

39. * $\uparrow$ Thrips orientalis (Bagnall 1915) - All agroecological regions

Carissa carandas L. (Apocynaceae), Carissa spinarum L. (Apocynaceae), Dichrostachys cinerea (L.) Wight \& Arn. (Fabaceae), Ervatamia divaricata (L.) Burkill (Apocynaceae), Jasminum grandiflorum L. ( Oleaceae), Jasminum sambac (L.) Ait. (Oleaceae), Kopsia fruticosa (Ker-Gawl.) A.DC. (Apocynaceae), Phyllanthus emblica L. (Euphorbiaceae), Vitex negundo L. (Verbanaceae).

40. †Thrips palmi Karny 1925 - All agroecological regions Abelmoschus esculentus (L.) Moench (Malvaceae), Amaranthus spinosus L.

(Amaranthaceae), Basilicum polystachyon (L.) Moench (Lamiaceae), Bellis sp. Callistephus chinensis (L.) Nees (Asteraceae), Canvalia ensiformis (L.)DC. ( Fabaceae), Capsicum annum L. (Solanaceae), Capsicum frutescens L. (Solanaceae), Celosia argentia L. (Amaranthaceae), 
Chrysanthemum segetum L. (Asteraceae), Coriandrum sativum L. (Apiaceae), Cucumis melo L. (Cucurbitaceae), Cucumis sativus L. (Cucurbitaceae), Cucurbita pepo L. (Cucurbitaceae), Dacus carota L. (Apiaceae), Eleusine coracana (L.) (Poaceae), Fragaria vesca L. (Rosaceae), Gerbera jamesonii Adlam (Asteraceae), Helianthus annuus L. (Asteraceae), Hippeastrum puniceum (Lam.) Kuntze (Amaryllidaceae), Ipomoea batatas (L.)Lam. (Convolvulaceae), Limonium sp. (Plumbaginaceae), Luffa acutangula (L.)Roxb.( Cucurbitaceae), Luffa cylindrica (L.) M.Roemer (Cucurbitaceae), Momordica charantia L.( Cucurbitaceae), Ocimum basilicum L. (Lamiaceae), Ocimum tenuiflorum L. (Lamiaceae), Phaseolus lunatus L. (Fabaceae), Phyllanthus emblica L.( Euphorbiaceae), Pteridium sp. (Dennstaedtiaceae), Pyrus communis L. (Rosaceae), Solanum macrocarpon L. (Solanaceae), Solanum mauritianum Scop. (Solanaceae), Solanum sp. (Solanaceae), Solanum tuberosum L. (Solanaceae), Solanum violaceum Ortega. (Solanaceae), Stachytarpheta urticaelifolia (Salisb.) Sims (Verbenaceae), Strobilanthes calycina Nees (Acanthaceae), Strobilanthus sp. (Acanthaceae), Vigna mungo (L.) (Fabaceae), Vigna radiata L.(Wilczek) (Fabaceae), Vigna unguiculata(L.) Walp. (Fabaceae), Vigna unguiculata sesquipedalis(L.) Verdc. (Fabaceae), Zantedeschia aethiopica (L.) Spreng. (Araceae).

Damage: Scarring, browning and discolouration of flowers and leaves.

41. * $\uparrow$ Thrips parvispinus (Karny 1922) - Makandura, Marassana and Peradeniya Carica papaya L. (Caricaceae), Verbena bonariensis L. (Verbenaceae).

42. $†$ Thrips simplex (Morison 1930) (Gladiolus Thrips) - confined toUpcountry Wet zone Aristea ecklonii Baker (Iridaceae), Canna generalis L. (Cannaceae), Gladiolus sp. (Iridaceae), Watsonia pyramidata (Iridaceae), Zantedeschia aethiopica (L.) Spreng. (Araceae).

Damage: Scarring, browning and discolouration of flowers and leaves in Gladiolus.

43. * $†$ Thrips subnudula (Karny 1926) - All agroecological regions

Aerva javanica (Burm.f.) Juss.ex Schult. (Amaranthaceae), Calotropis gigantean (L.) R.Br. (Asclepidaceae), Cinnamomum verum J.Presl. (Lauraceae), Mangifera indica (L.) (Anacardiaceae), Mimosa pudica L. (Fabaceae), Spondias dulcis Sol. ex Parkinson. (Anacardiaceae).

44. * $†$ Thrips sumatrensis Priesner 1934 - All agroecological regions

Caesalpinia pulcherrima (L.) Sw. (Fabaceae), Canna generalis L. (Cannaceae), Dahlia hortensis (Asteraceae), Dahlia pinnata Cav. (Asteraceae), Gliricidia sepium (Jacq.)Walp. (Fabaceae), Helianthus annuus L. (Asteraceae), Ludwigia decurrens Walt. (Onagraceae), Melastoma malabathricum L.(Melastomataceae), Samanea saman (Jacq.) Merr. (Fabaceae), Sarca asoca (Roxb.) de Wild (Fabaceae), Sesamum indicum L. (Pedaliaceae), Sesbania grandiflora (L.) Poir. (Fabaceae), Tecoma stans (L.) Kunth (Bignoniaceae), Urena lobata L. (Malvaceae), Zinnia sp. (Asteraceae).

Damage: Scarring, browning and discolouration of flowers.

45. $\uparrow$ Thrips tabaci Lindeman 1889 (Onion thrips) - Wet and Intermediate zones

Allium cepa L. (Alliaceae), Allium ampeloprasum L. (Alliaceae), Bellis sp. (Asteraceae), Callistephus chinensis (L.) Nees (Asteraceae), Chrysanthemum segetum L. (Asteraceae), Cleome chelidonii L.f. (Capparaceae) Coreopsis grandiflora Hogg ex Sweet (Asteraceae), Dianthus caryophyllus L. (Caryophyllaceae), Euphatorium sp. (Asteraceae), Gypsophila paniculata L. (Caryophyllaceae) Hydrangea macrophylla (Thunb.) Ser. (Hydrangeaceae), Limonium sp. (Plumbaginaceae) Ocimum basilicum L. (Lamiaceae), Ocimum tenuiflorum L. (Lamiaceae), Spathiphyllum sp. (Araceae).

Damage: Streaking and spots in leaves of onion and leeks.

46. Thrips sp.1- Mid and Upcountry Wet zone and Upcountry Intermediate zone

Aleurites montana (Lour.) E. Wilson (Euphorbiaceae), Alstonia scholaris (L.) R.Br. (Apocynaceae), Bougainvillea spectabilis Willd. (Nyctaginaceae), Calotropis gigantea (L.) R.Br. (Asclepidaceae), Cinnamomum verum J. Presl (Lauraceae), Citrus grandis (L.) Osbeck. (Rutaceae), Coffea arabica L. (Rubiaceae), Connarus monocarpus L. (Connaraceae), Couroupita 
surinamensis Mart. ex Berg (Lecythidaceae), Mangifera indica (L.) (Anacardiaceae), Persea americana Miller (Lauraceae), Plumbago auriculata Lam. (Plumbaginaceae), Saraca thaipingensis Prain (Fabaceae).

47. Thripinae sp.1 - Sinharaja forest

Schumacheria castaneifolia Vahl. (Dilleniaceae).

48. Thripinae sp.5 - Peradeniya

Sarca asoca (Roxb.) de Wild (Fabaceae).

\section{SUBORDER TUBILIFERA ${ }^{8}$}

\section{Family Phlaeothripidae- Subfamily Idolothripinae}

49. Diaphorothrips unguipes Karny 1920 - Peradeniya

Bark of freshly felled trunk of Mangifera indica L. (Anacardiaceae).

Fungus feeding species.

50. Dinothrips spinosus (Schmutz 1913) - Peradeniya and Hakgala

Albizia sp. (Fabaceae), Artocarpus heterophyllus Lam. (Moraceae), Ficus exasperata Vahl.

(Moraceae). Fungus feeding species

51. Elaphrothrips greeni (Bagnall 1914) - Peradeniya

Fungus feeding species

52. Elaphrothrips malayensis (Bagnall 1909) - Matale and Knuckles forest range

Piper nigrum L. (Piperaceae).

Damage: Leaf galls, Fungus feeding species.

\section{Family Phlaeothripidae - Subfamily Phlaeothripinae}

53. Androthrips flavipes Schmutz 1913 - Matale

Piper nigrum L. (Piperaceae)

Damage: Leaf galls, a predatory species.

54. **Apelaunothrips sp. - Monaragala and Kokagala

In leaf litter, fungus feeding species.

55. ** Dolichothrips sp. - Dry, Wet and Intermediate zones

Abutilon indicum (L.) Sweet (Malvaceae), Averrhoa bilimbi L. (Oxalidaceae), Bridelia retusa (L.) A. Juss. (Euphorbiaceae), Ficus exasperata Vahl (Moraceae), Macaranga peltata (Roxb.) Muell. Arg., (Euphorbiaceae), Melastoma malabathricum L. (Melastomataceae), Terminalia bellirica (Gaertn.) Roxb. (Combretaceae).

56. Gigantothrips tibialis Bagnall 1921 - Knuckles Forest and Matale

Ficus benjamina L. (Moraceae) and Careya arborea Roxb. (Lecythidaceae).

Damage: Leaf galls in $F$. benjamina. Scarring, browning and discolouration of leaves in

C. arborea.

\footnotetext{
${ }^{8}$ Conventionally, the Tubulifera are classified into a single family Phlaeothripidae, which is divided into two subfamilies, Idolothripinae and Phlaeothripinae, based on the width of maxillary stylets, 5-15 $\mu \mathrm{m}$ in the former and 3-5 $\mu \mathrm{m}$ in the latter. Based on the structure of the wing surface, Bhatti (1991) considers that these two groups are paraphyletic. And 14 families have been included in Tubulifera (Bhatti 1988, 1992, 1995, 1998a-d).
} 
57. ** $\uparrow$ Gynaikothrips ficorum (Marchal 1908) - Mid country Wet zone Ficus benjamina L. (Moraceae) \& Thunbergia sp. (Acanthaceae). Damage: Leaf galls.

58. *Gynaikothrips sp. - Sita Eliya. Euodia lunu-ankenda (Gaertn.) (Rutaceae). Damage: Leaf fold galls.

59. $†$ Haplothrips ceylonicus Schmutz 1913 - Hakgala, Maha Illuppallma and Peradeniya Achyranthus aspera L. (Amaranthaceae), Aerva javanica (Burm.f.) Juss.ex Schult. (Amaranthaceae), Alternanthera sessilis (L.) DC. (Amaranthaceae), Calicarpa sp. (Verbenaceae), Carex kyllingia Endl. (Cyperaceae), Cymbopogon nardus (L.) Rendle (Poaceae), Eleusine coracana (L.) (Poaceae), Eupatorium riparium Regel (Asteraceae), Hemigraphis alternata (N.L.Burm.) (Acanthaceae), Hyptis capitata Jacq. (Lamiaceae), Impatiens balsamina L. (Balsaminaceae), Laurentia longifolia (L.) Endl. (Campanulaceae), Pennisetum polystachion (L.) Shult (Poaceae), Petiveria alliaceae L. (Phytolacaceae), Wendlandia bicuspidate Wight \& Arn. (Rubiaceae).

60. $\dagger$ Haplothrips ganglbaueri Schmutz 1913 - All agro ecological regions

Ageratum houstonianum Miller (Asteraceae), Carex kyllingia Endl. (Cyperaceae), Carex leucantha Arn.ex Boott (Cyperaceae), Bothricholoa pertusa (L.) A.Camus (Poaceae), Brachiara milliformis (Poaceae), Brachiaria sp. (Poaceae), Celosia argentia L (Amaranthaceae), Celosia sp.(Amaranthaceae), Cynodon dactylon (L.) Pers. (Poaceae), Cyperus difformis L. (Cyperaceae), Cyperus iria L. (Cyperaceae), Cyperus pilosus Vahl (Cyperaceae), Dactyloctenium aegyptium (L.) Willd.(Poaceae), Digitaria ciliaris (Retz.) Koeler (Poaceae), Digitaria marginata? (Poaceae), Dimeria alata ?(Poaceae), Echinichola crusgalli (L.) P.Baeauv. (Poaceae), Echinochola colona (L.) Link (Poaceae), Eleusine coracana (L.) Gaertn., Eleusine indica (L.) Gaertn. (Poaceae), Eleusine sp. (Poaceae), Eragrostis curvula (Schrad.) Nees (Poaceae), Eragrostis diplachnoides Steud.(Poaceae), Eregeron sublyratus DC. (Asteraceae), Eragostis unioloides (Retz.) Nees ex Steud. (Poaceae), Ischaemum ciliare Retz. (Poaceae), Leptochola chinensis (L.) Nees (Poaceae), MI 1-Introduced grass (Poaceae), Oryza sativa L. (Poaceae), Panicum maximum Jacq. (Poaceae), Eulalia trispicata (Schult.) Henrard (Poaceae), Panicum repens L. (Poaceae), Panicum sp. (Poaceae), Paspalum conjugatum Berguis (Poaceae), Pennisetum polystachion (L.) Shult (Poaceae), Rhynchospora corymbosa (L.) Britton (Poaceae), Sacciolepsis indica L. (Chase) (Poaceae), Sesamum indicum L. (Pedaliaceae), Setaria barbata (Lam.) Kunth (Poaceae), Setaria geniculata auct. non (Wild.) Beauv. (Poaceae), Setaria palledifusa (Poaceae), SR 9-Unidentified (Cyperaceae), Stachytarpheta urticaelifolia (Salisb.) Sims (Verbenaceae), Symplocos cochinchinensis ((Lour.) S. Moore (Symplocaceae), Themeda triandra Forssk (Poaceae), Themeda villosa (Poir.) A. Camus (Poaceae), Zea mays L. (Poaceae).

61. †Haplothrips gowdeyi (Franklin 1908) - All agro ecological regions

Acacia pennata (L.) Wild. (Fabaceae), Achyranthes aspera L. (Amaranthaceae), Ageratum conyzoides L. (Asteraceae), Abelmoschus esculentus (L.) Moench (Malvaceae), Amaranthus spinosus L. (Amaranthaceae), Asteracantha longifolia Nees. (Acanthaceae), Axonopus affinis Chase (Poaceae), Axonopus compressus (Sw.) P.Beauv. (Poaceae), Basilicum polystachyon (L.) (Moench) (Lamiaceae), Bidens pilosus L. (Asteraceae), Bidens sp. (Asteraceae), Catharanthus roseus (L.) G. Don (Apocynaceae), Callicarpa tomentosa (L.) Murr. (Verbenaceae), Callistephus chinensis (L.) Nees (Asteraceae), Capsicum frutescens L. (Solanaceae), Catharanthus roseus (L.) G. Don (Apocynaceae), Canna generalis L. (Cannaceae), Celosia argentia L. (Amaranthaceae), Cipadessa baccifera (Roth) Miq. (Meliaceae), Costus speciosus (Koenig) Smith (Zingiberaceae), Cestraum elegans (Brongn.) Schlecht. (Solanaceae), Dahlia x hortensis (Asteraceae), Elephantopus scaber L. (Asteraceae), Emilia exserta Fosberg (Asteraceae), Emilia zeylanica C.B.Clarke (Asteraceae), Erigeron sublyratus DC. (Asteraceae), Eupatorium sp. (Asteraceae), Euphorbia sp. (Euphorbiaceae), Evolvulus alsinoides (L.) L. (Convolvulaceae), Gerbera jamesonii Adlam (Asteraceae), Gomphrena globosa L. (Amaranthaceae), Hediyotis trimenii Deb \& Dutta (Rubiaceae), Melilotus indicus (L.) All. (Fabaceae), Mimosa invisa Mart. (Fabaceae), Mangifera indica (Anacardiaceae), Mimosa pudica L. (Fabaceae), Psidium guajava L. (Myrtaceae), Persicaria capitata (Buch Ham. in D.Don) H. Gross (Polygonaceae), Phyllanthus 
deblis Klein ex Willd (Euphorbiaceae), Punica granatum L. (Punicaceae), Saraca asoca (Roxb.) de Wild (Fabaceae), Solidago canadensis L. (Asteraceae), Spilanthes iabadicensis A.H.Moore (Asteraceae), Stachytarpheta indica (L.) Vahl (Verbenaceae), Strobilanthes sexennnis Nees (Acanthaceae), Tagetes erecta L. (Asteraceae), Themeda tremeula (Steud.) Hack. (Poaceae), Tridax procumbens L. (Asteraceae), Vernonia cinerea (L.) Less. (Asteraceae), Vetiveria zizanioides (L.) Nash (Poaceae), Wedelia chinensis (Osbeck) Merr. (Asteraceae).

62. Haplothrips sp.3 - Mid country and Upcountry

Amaranthus spinosus L. (Amaranthaceae), Canna generalis L. (Cannaceae), Cestrum elegans (Brongn.) Schlecht. (Solanaceae), Coffea arabica L. (Rubiaceae), Cymbopogon nardus (L.) Rendle (Poaceae ), Mangifera indica(L.) (Anacardiaceae), Psidium guajava L. (Myrtaceae), Tagetes erecta L. (Asteraceae).

63. **Karnyothrips melaleucus Bagnall 1911 - Peradeniya

Collected from leaf litter, a predatory species.

64. Liothrips floridensis (Watson 1913) - Peradeniya Cinnamomum camphora (L.) J. Presl (Lauraceae).

Damage: Scarring and browning of leaves.

65. $†$ Liothrips karnyi (Bagnall 1914) - Wet zone Piper nigrum L (Piperaceae).

Damage: Leaf galls.

66. ** Membrothrips sp. - Dambulla, Matale, Mahallluppallma, Meewathura and Peradeniya Jasminum sambac (L.) Ait. (Oleaceae), Tectona grandis L.f. (Verbenaceae).

67. ** Praepodothrips sp. - Gannoruwa, Marassana and Naula Lycopersicon esculentum Miller (Solanaceae).

68. ** Sphingothrips trachypogon (Karny 1923) - Peradeniya Diospyros atrata (Thw.) Alston, Diospyros malabarica (Desr.) Kostel (Ebenaceae). Damage: Scarring and browning of leaves.

69. Phlaeothripinae sp.1 - Peradeniya and Sinharaja forest Vateria copallifera (Retz.) Alston, Vateria copallifera (Retz.) Alston (Dipterocarpaceae).

70. Phlaeothripinae sp.2 - Sinharaja forest Syzygium alubo Kosterm (Myrtaceae).

71. Phlaeothripinae sp.3 - Peradeniya In leaf litter, fungus feeding species.

72. Phlaeothripinae sp.4 - Peradeniya In leaf litter, fungus feeding species.

* Species previously not recorded from Sri Lanka (25 species in 18 genera)

** Genera previously not recorded from Sri Lanka (18 genera)

$\uparrow$ Pest thrips species (42) based on Moritz et al. (2001) 